\title{
Investigation on College Students' Financial Management Behavior and Research on Guiding Strategies
}

\author{
Zhedi Wan ${ }^{1}$ \\ ${ }^{1}$ Sichuan Agricultural University, Chengdu, Sichuan
}

\begin{abstract}
The rapid development of information technology and economy has accelerated the integration of Internet and Finance, and contributed to changes in consumers' attitudes and behaviors toward money. In the era of Internet consumer finance, more and more college students join the Internet financial management team. As a special consumer group, they occupy an important position, and their financial management behavior is concerned by the society. In this paper, college students in Sichuan Province are investigated by random sampling, and 514 valid questionnaires are collected and analyzed to study the characteristics of college students' financial behavior and the main factors affecting their investment tendency, so as to improve the quality of college students' consumption finance and optimize their financial ecology, and finally realize the sustainable development of campus finance.
\end{abstract}

\section{Introduction}

Contemporary college students are open-minded in embracing new staff, who have developed a novel understanding of consumption and close relationship with the Internet.[1] Therefore, they have a strong passion for the advent and development of Internet finance.[2] With the increasing involvement of Internet finance in people's daily life, more people are taking advantage of it, among which college students are the main force.[3] Some college students are rational in the selection of financial products, [4] while there are college students who borrow beyond their repayment capacity to their desires.[5] Based on observations of students, this paper studied both positive and negative impacts of Internet finance on college students.

Based on current researches, this paper took college students in Sichuan

Province as the subjects of investigation via online surveys and offline interviews. A total of 529 questionnaires were distributed, of which 514 were valid, with an effective rate of $97.16 \%$. The Sichuan University and Sichuan Agricultural University were interviewed, based on which this paper made an in-depth analysis to explore the demands of college students in terms of Internet consumption. This paper also proposed suggestions suitable for different groups to promote the development of Internet finance.

\section{Money Management of College Students in the Era of Internet Consumer Finance}

\subsection{Status quo of financial management of college students}

Before the advent of Internet finance, financial technology was not accessible to the public, and few people had extra money for financial management. College students used to put money in the bank to collect interests and minimize currency depreciation. Moreover, without a proper understanding of finance, few college students would purchase financial products. However, with the rapid development and vigorous rise of financial technology, college students nowadays have come into contact with financial management under the influence of various factors. However, impulsive consumption, irrational financial management and misunderstanding of finance have prevented them from fitting well into the era of Internet consumer finance.

\subsubsection{Changes in the attitudes of college students toward financial management}

The increase of idle funds and the emergence of diverse Internet financial products are available for college students via various channels and forms, which have narrowed the distance between college students and online financial management, integrating financial technology with the daily consumption and money management of college students. Compared with traditional bank deposits, Internet financial products such 
as Yu'E Bao of Alibaba and "Wealth" of WeChat are more efficient, and allow investors to check the return at any time. Advanced Internet technology makes it easier for college students to access more financial information, who no longer save all their money in the bank.

\subsubsection{Misunderstandings of financial management among college students}

(1) The financial technology progresses much faster than evolving understanding of financial management

As college students used to neglect the importance of financial management, it is impossible for them to develop a full understanding of financial products in a short time. Most of them behave like before the advent of the Internet consumer finance, who would rush to purchase financial product with the money they get from their parents in the beginning of every month. As a result, the financial product proves not profitable, or even causes loss at the end of the month. After all, the problem stems from inconsistency between their understanding of money management and the development of Internet consumer finance, which fail to synchronize for joint development.

(2) Irrational planning of idle funds

As shown in Figure 1, most college students have a poor performance in financial management due to the absence of complete planning before making investment. College students mainly earn income through living expenses provided by their parents and family members, scholarships awarded by schools, and part-time jobs after school. The lack of planning for idle funds prevents them from predicting future returns. They need to further develop the capacity to quantify risks and predict losses under greater risks.

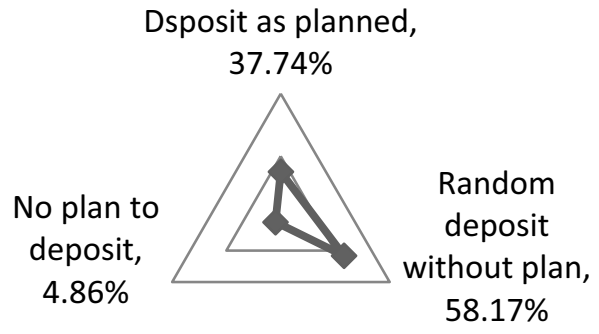

Figure 1 How College Students Behave in Financial Management

(3) The lack of awareness and understanding of financial management

As can be seen from Figure 2, there are more than half of college students who know nothing about finance, with very few students adept at financial management.
Most of them join in online financial activities without a decent understanding of it. Ignorance, misunderstandings and unhealthy consumption habits have jointly contributed to this phenomenon.



Figure 2 Understanding of Financial Management among Different Grades of Students

\subsection{Status quo of online credit of college students}

Consumer demand, stimulated by consumer credit, is increasing year by year, which in turn, drives market economy to press ahead. The arrival of financial technology has ushered in a new era for Internet companies, as evidenced by their efforts in business expansion and the introduction of brand-new products. Consumers aged from 20 to 25 , including a certain proportion of college students, are emerging in the consumer credit market. By living paycheck to paycheck, 
they fulfill their desire of consumption by borrowing from Alibaba's "Ant Credit Pay" and Jingdong's "Campus Loan". Table 1 shows that almost all college students have used Internet consumer credit, accounting for $92.41 \%$, while $35.80 \%$ of them use it more than three times a month. Various consumer financial platforms have penetrated into the life of college students from all aspects. There are college students who would fulfill their desire of consumption through Internet consumer credits without considering their financial conditions.

Table 1 Online consumer credit of college students

\begin{tabular}{ccc}
\hline Use of Online Consumer Credit & Yes & No \\
\hline Number of People & 475 & 39 \\
Proportion & $92.41 \%$ & $7.59 \%$
\end{tabular}

\subsubsection{Risks of online consumer credit for college students}

Alibaba's "Ant Credit Pay" and Jingdong's "Campus Loan" weaken the scenario of paying by cash in the real world. When people's desire cannot be fulfilled because they don't have enough money, online consumer credit offers to help. Installment payment serves as a shortcut for college students, who tend to ignore the extremely high interests and the time value of money behind.

Financial products like "campus loan" and "naked loan" are inducing college students to spend way beyond their purchasing power and leading them on the track of repaying debt with private information, which has caused issues of moral considerations. It has even threatened the health and life of college students, who suffer from mounting pressure from lenders pushing them to repay the debt. Things like these have posed challenges to the development of Internet consumer finance, and are endangering the interests of college students, a violation of the intention of Internet consumer finance in the first place.

\subsubsection{Causes of Internet credit risks for college students}

\section{(1) Weak self-control}

Despite living a better life now, some college students are craze to vie with each other and addicted to purchasing staff. As shown in Figure 3, around 36.38\% of college students didn't read the contract of financial products carefully and had no awareness of protecting their legal rights, thus stepping into the trap of fraudulent lenders.

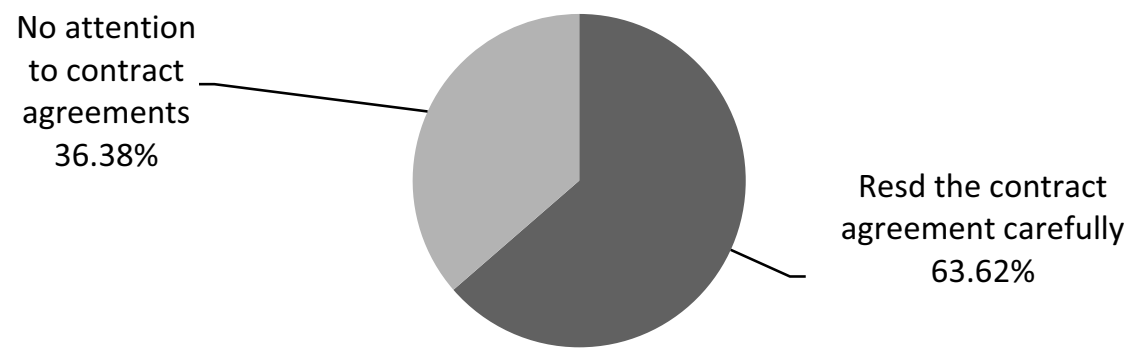

Figure 3 Survey of How College Students Read Contract When Purchasing Products of Internet Consumer Credit

Covid-19 has a huge impact on global economy. To implement social distancing, colleges and universities have shifted to online teaching, for which college students are forced to stay at home, with no money from parents as before. Therefore, some of them have no money to pay back loan, resulting in bad record of personal credit.

(2) Loopholes in the security of Internet credit platform

The "campus loan" didn't protect the privacy of users. On the contrary, the lender took advantage of students' desire for quick money, simplified procedures and lowered threshold of loan application to induce college students to spend beyond budget, causing tremendous losses for these students.

(3) Sluggish policies and regulations

The development of Internet consumer finance and renovation of financial systems move far ahead of policies and regulations concerning the two sectors, for which current policies fail to regulate existing platforms of Internet consumer finance. Some platforms take advantage of the loopholes, resulting in problems beyond the reach of laws and legislations.

\subsection{Status quo of Internet financial management of college students}

With the popularization of mobile payment, financial products like Yu' E Bao, Mini Fund, and automatic investment plan (AIP) offer a chance for college students to engage in Internet financial management with limited funds. However, there are problems for college students, their family and schools. 


\subsubsection{Purchasing financial products carelessly}

Transforming from an onlooker of the financial market into a participant, college students are more interested in "earning" than "saving". However, to get an ideal return, they need to be equipped with expertise of financial management. From Figure 4, it is noted that some college students prefer financial products with strong liquidity, low risks and low return, as evidenced by their purchase of limited types of Internet financial products. However, some students, attracted by products of high return, ignore potential risks behind it. Without an in-depth understanding of Internet financial products and considerations of overall return and risks, they are heading to the wrong products for investment.

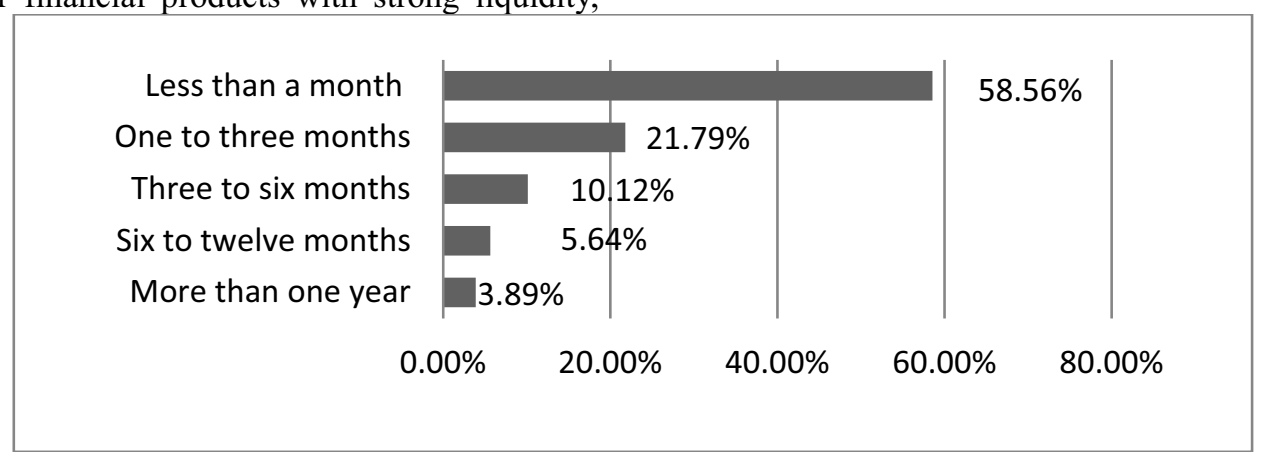

Figure 4 Preference of Liquidity among College Students for Financial Products

\subsubsection{Ignorance of financial management in family and school}

Most of the college students are born in the $21^{\text {st }}$ century, with care from grandparents and parents in all aspects of their life. Whenever they have a need, parents will do their best to satisfy them, without giving them proper guidance on consumption and money management. In addition, most parents concentrate on the academic performance of their children, and are used to rewarding them with physical stimuli for their academic progress. Therefore, college students tend to have no awareness of financial management, with a lot of them spending over budget. Also, schools focus on the academic performance of students as well as their mental and physical health, without educating students of financial management. This "ignorance" partially contributed to the inability of students in financial management.

\section{Suggestions for College Students in the Era of Internet Consumer Finance}

Targeting the abovementioned problems in the era of Internet consumer finance, government, society, schools and college students need to work together to give a full play of their roles and change the situation.

(1) Establish a prevention mechanism to reduce delinquencies of college students

Education is far from enough. It is necessary to introduce clear regulations and policies to fill the blank of Internet consumer credit, eliminate loopholes, and ensure the implementation and timely follow-up of policies and regulations. Meanwhile, regulations need to place more restraints upon the platform of the Internet consumer credit to safeguard the rights and interests of college students. The government should play a guiding role in establishing an information network between the platform of Internet consumer credit, public security, major banks and universities to facilitate information sharing and interconnection. It is essential to investigate and evaluate the repayment capacity and overdue risks of college students under the risk prevention mechanism. Policy support and regulation should work together to stimulate the healthy development of Internet consumer credit.

(2) Cooperation between social and legislative functions to purify the environment of consumer credit

While the government strengthens law enforcement, the society should also play a guiding role in a timely and effective manner to supervise Internet consumer finance in all aspects and eliminate loopholes. Meanwhile, the society should vigorously advocate rational consumption in public and guide the operation of Internet credit platform. By giving contemporary college students positive guidance on financial management, we will create a healthy environment of consumption and financial management for college students.

(3) Enhance education of consumption and Internet financial management among college students

When formulating training programs, schools need to introduce the concept of rational consumption while college counselors should communicate with students regularly, taking care of their mental health and consumption behaviors. By strengthening guidance and popularizing common traps of internet finance, schools can help alert college students of dangers from internet credit. In addition, most of the existing financial courses in school focus on entrepreneurship. However, financial management is the key to students' survival after graduation. Therefore, schools should include Internet consumer finance in the curriculum to improve their capacity of financial management and increase their awareness of law and legislations concerning financial products.

(4) Establish a correct understanding of consumption and financial management for college students

Rational consumption serves as the premise of financial management and investment in Internet financial products. College students need to make a detailed budget planning in their daily life and avoid 
comparing with others. When purchasing Internet financial products, they need to be alerted of potential risks and estimate their repayment capacity. Equipped with a correct understanding of Internet finance and expertise, they will do much better in the selection of financial products in a portfolio to avoid risks. There is no uniform standard of risk and return. College students should minimize risks and maximize return by making rational plans of investment based on their own situation.

\section{Conclusion}

In today's electronic era, Internet consumer finance is speeding up the pace of entering college students. In order to take the lead in the construction of socialist economy, college students should set up an example of the times, establish correct consumption and financial management concepts, actively study financial management knowledge, improve the vigilance of network credit, and make rational use of the "double-edged sword" of Internet financial management With the rapid development of science and technology, we can better realize our own value.

\section{Reference}

1. Anlan Li, Manting Luo, Chanfang Gu. Behavior analysis of College Students' choice of Internet financial products -- Based on Dongguan research [J]. China market, 2020 (10): 37-39+ 48

2. Rui Li, Shu Yang. Research on the current situation and demand of College Students' Internet financial management under the background of Internet finance [J]. Times finance, 2020 (15): 128-130

3. Hongbo Yan. Current situation and suggestions of College Students' financial management under the background of Internet finance [J]. Financial circles (Academic Edition), 2020 (09): 22-23

4. Zehu iHan, Jiangping Zhou, Fei Chen, Shouquan Zhu. Analysis of the influencing factors of College Students' financial management based on Internet plus financial background -- Based on the survey of universities in Xuzhou, Jiangsu, [J]. China business theory, 2019 (21): 222-224

5. Xianyong Huang, Huajing Zeng,haoxiong Yan. Consumption and financial management of college students based on Internet Finance: a case study of universities in Guangzhou [J]. Modern business industry: 2020 (27): 72-75 